\title{
ダイズの生育過程における根圈微生物叢の变動 圃場噮境下での遺伝子解析
}

ダイズは，トウモロコシ，イネ，コムギについで世界 で4番目に多く生産されている作物である。イネ科穀物 と異なり種子にタンパク質や脂質を多く含むことに加 え，イソフラボンやサポニンなどの機能性物質を含むこ とから，私たちの食生活に欠かせない作物の一つとなっ ている.ダイズの根には根粒菌が共生して窒素固定を行 い, 菌根菌は土壤中に張り巡らせた菌糸を介してリンな どのミネラルを植物に供給する。これらの共生微生物に 加え，根の近傍の土壤である「根圈」には多種多様な微 生物が存在し，コンソーシアムを形成して，植物の生育 と密接な関係を有することが近年明らかにされつつあ る ${ }^{(1,2)}$ (共生微生物については, 池田ら ${ }^{(3)}$ を参照)。これ らの根圈微生物に関しては古くから農業利用に向けた研 究が進められ, 有用微生物として農業資材化されている ものもある。

土壤微生物の $99 \%$ は培養不可能であると言われてい る.しかし, 近年, 次世代シーケンサーによる遺伝子配 列の解析法が確立され，培養を介さずに大量のDNA 配 列を調べることが可能となり，根圈微生物叢に関する情 報が飛躍的に増加した。根圈微生物研究の中で植物の遺 伝学や生理生化学に立脚した研究は, 従来グロースチャ ンバーなど規格化したモデル環境で行ったものが多い が，農業への活用に向けては固場環境下での解析も併せ て進めなければならない。そこで，筆者らは圈場環境下 でのダイズと根圈微生物の相互作用を調べるために，ダ イズ圃場において，植物の生育過程を通じた根圈微生物 の変動を追跡した。播種前の土壤を採取した後, 開花直 後 (R2 期)，子実が肥大する枝豆の時期 ( $\mathrm{R} 6$ 期)，成熟 期 (R8期) の根圈土壌（植物の根に付着している土壤） とバルク土壤（植物から離れた土壤）を採取した。 それ ぞれの試料から DNAを抽出し，16S rRNA配列をPCR により増幅した後, 次世代シーケンサーによるシーケン シングと微生物解析用ソフトウェアMothurを用いた解 析を行った。その結果, 生育過程による微生物叢の変動 は，バルク土畩と比べて根圈土壤で顕著に大きいことが 明らかとなった．特に，根圈で大きく変動する微生物の 配列を調べたところ，Bacillus 属やBradyrhizobium 属 などバルク土畩と比べて根圈に多く生息し，植物の生育
を促進する機能が知られている微生物（PGPR: Plant Growth Promoting Rhizobacteria）を含む属の配列が多 く見いだされた (4). バルク土畩では生育段階により特に 大きな変動が認められなかったことから，根圈土壤での 根圈微生物の変動は，季節変化などの環境要因はむしろ 小さく，植物の生育による影響が強く表れていることが 示唆され, ダイズが生育過程で根圈微生物への働きかけ を変化させていることが推測された（図1）.

圃場環境下において，ダイズの生育過程に依存して根 圈微生物が変動することが示されたことから，その要因 が何かを解明することが次の課題である，植物の生育が 根圈微生物へ与える影響としては, 細胞壁成分や根細胞 の離脱のほか, 不溶性の粘液質のムシゲル，代謝物の分 泌が挙げられる．植物根から分泌される代謝物は根分泌 物（または，根滲出物）と総称される。これらは根細胞 の離脱などほかの要因とは異なり，植物のエネルギーを 使った代謝・輸送過程の制御下で起こる生物学的現象で あり，植物が根圈環境を制御するための最も重要な因子 の一つであると考えられる(5).これらの代謝物の分泌义 カニズムには不明な点が多いが，菌根菌の分枝誘導物質 であるストリゴラクトンを輸送する ABC (ATP-binding cassette）型輸送体や有機酸を分泌するMATE（Multidrug and toxic compound extrusion）型輸送体など，複 数の膜輸送体も同定されている.ダイズにおいては，根

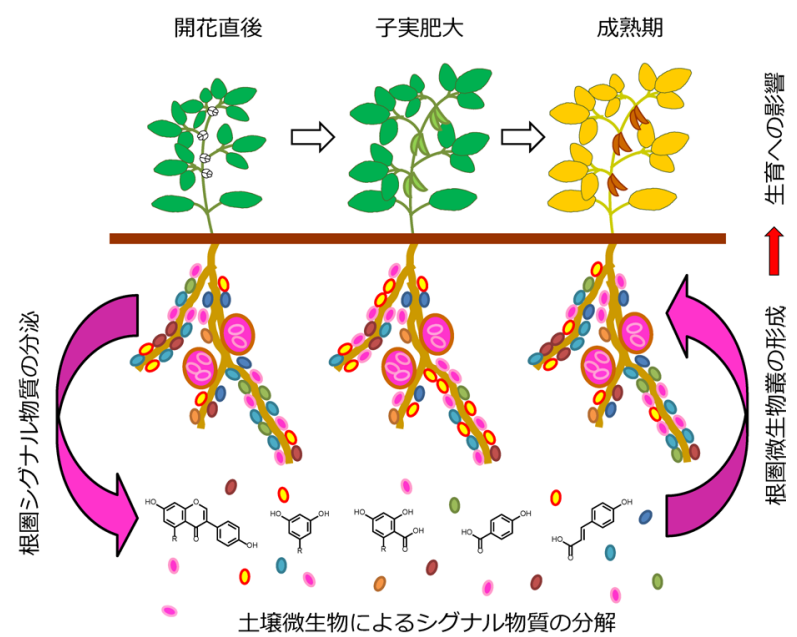

図 1 - 圑場環境下でのダイズ生育過程における根圏微生物の変動 


\section{今日の話題}

から分泌される代謝物には糖やアミノ酸などの一次代謝 産物に加え, ダイゼインやゲニステインなどのイソフラ ボンが多く含まれている，ダイズのイソフラボンは，根 から ATPの加水分解エネルギーを利用した輸送による ゲニステイン分泌経路(6) と，イソフラボンの蓄積形態で ある配糖体やマロニル配糖体が未知の経路によりアポプ ラストに分泌された後, 細胞外局在性の $\beta$-グルコシダー ゼによって加水分解される経路 ${ }^{(7)}$ が提唱されている. し かし，アグリコンを含めフラボノイド誘導体の分泌に関 与する輸送，分泌系のタンパク質は同定されていない.

根圈微生物の解析においては, 16S rRNA配列の解析 や,メタゲノム解析, メタトランスクリプトーム解析に 加え, 植物-根圈微生物相互作用の鍵を握る代謝物の動 態を網羅的に解析する「メタメタボローム解析」も重要 になる．しかし，分泌された代謝物が根圈でどのような 運命をたどるのかについてもあまり理解が進んでいない. フラボノイドの土壤中での半減期は論文により数時間か ら数日まで大きく異なり, ダイズの根から分泌されるダ イゼインやゲニステインに関しては，最短では6分とい う報告もある ${ }^{(8)}$. しかし，土壤中から植物代謝物を抽出 する手法は確立されているとは言い難く, 土䁃の化学性 や微生物性によっても動態が大きく異なり，これが大き な変動の一因と考えられる( ${ }^{(9)}$. 根圈メ夕ボローム技術の 確立と, ブラックボックスである根圈での代謝物の動態 に光を当てることにより, 根圈での植物微生物相互作用 研究にブレークスルーがもたらされるものと期待される.

地球上の人口は今世紀中には 90 億人を超えると予想 されており，エネルギー消費や環境負荷を低減した持続 的な方法でのダイズの収量増加が望まれている．根粒菌 や菌根菌は古くからダイズ生産を支える重要な根圈微生 物であったが，これまでその役割が明らかにされていな かった多くの根圈微生物の秘められた能力を活かした新 しい農業は，持続型農業実現の一翼を担うと考えられ る. 現在, 遺伝子や代謝産物の解析手法の高度化を受 け, 根圈微生物の積極的な活用に向けた育種や, 根圈微 生物機能を活性化する新たな農業資材の開発が世界的に 進められている. ダイズの代謝物や根圈微生物叢の研究 を通して，微生物資材としての利用にとどまらない斬新 な根圈微生物活用型の農業の実現を目指していきたい.

本研究の成果の一部は農林水産省委託プロジェクト 「ゲノム情報を活用した農産物の次世代基盤技術の開発 プロジェクト」による.

1) R. L. Berendsen, C. M. J. Pieterse \& P. Bakker: Trends Plant Sci., 17, 478 (2012).

2) L. Philippot, J. M. Raaijmakers, P. Lemanceau \& W. H. van der Putten: Nat. Rev. Microbiol., 11, 789 (2013).

3) 池田成志, 鶴丸博人, 大久保 卓, 岡崎和之, 南澤 究 : 化学と生物, 51, 462 (2013).

4) A. Sugiyama, Y. Ueda, T. Zushi, H. Takase \& K. Yazaki: PLoS ONE, 9, e100709 (2014).

5) A. Sugiyama \& K. Yazaki: "Secretions and Exudates in Biological Systems," eds. by J. M. Vivanco \& F. Baluška, Springer, 2012, p. 27.

6) A. Sugiyama, N. Shitan \& K. Yazaki: Plant Physiol., 144, 2000 (2007).

7) H. Suzuki, S. Takahashi, R. Watanabe, Y. Fukushima, N. Fujita, A. Noguchi, R. Yokoyama, K. Nishitani, T. Nishino \& T. Nakayama: J. Biol. Chem., 281, 30251 (2006).

8) Z. Y. Guo, C. H. Kong, J. G. Wang \& Y. F. Wang: Soil Biol. Biochem., 43, 2257 (2011).

9) A. Sugiyama \& K. Yazaki: Plant Biotechnol., 31, 431 (2014).

（杉山暁史，矢崎一史，京都大学生存圈研究所）

\section{プロフィル}
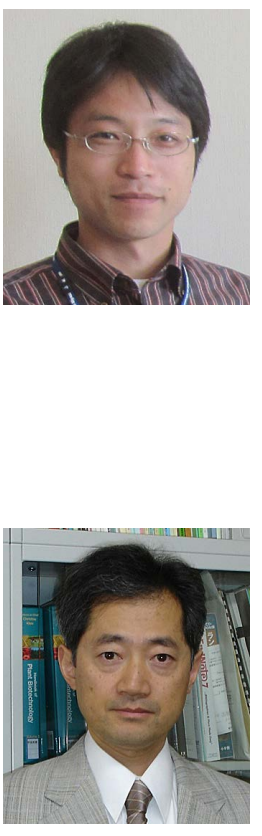

矢崎 一史 (Kazufumi YAZAKI)

$<$ 略歴 $>1981$ 年岡山大学薬学部薬学科卒 業 / 1986 年京都大学大学院薬学研究科博 士課程修了／同年岡山大学薬学部助手／ 1989年アレキサンダー・フォン・フンボ ルト財団奨学生 (ボン大学博士研究員, マックスプランク研究所博士研究員) / 1992 年京都大学薬学部助手 / 1996 年同大 学農学部助教授/1999年同大学大学院生 命科学研究科助教授 $/ 2002$ 年同大学木質 科学研究所教授 $/ 2004$ 年同大学生存圈研 究所教授 $/ 2014$ 年同所学際萌芽研究セン ター長併任, 現在に至る<研究テーマと抱 負 $>$ 植物の有用代謝産物の生合成と輸送制 御 $<$ 趣味 $>$ スキー, 飲食道楽 $<$ 所属研究室 ホームページ>http://www.rish.kyoto-u. ac.jp/lpge/index.html

Copyright （C２015 公益社団法人日本農芸化学会 DOI: 10.1271/kagakutoseibutsu.53.576 